\title{
KECENDERUNGAN NEUROTISME MELALUI KAREKTERISTIK EMOSIONAL DALAM PERSONALITI WATAK KARYA KREATIF
}

\section{(Neurotic Tendencies as Emotional Characteristics in the Personalities of Characters in Creative Works)}

\author{
Mohd Shahremy Ikmal Shahbudin \\ shahremyikmal@usm.my
}

Pusat Pengajian Ilmu Kemanusiaan, Universiti Sains Malaysia.

To cite this article (Rujukan artikel ini): Mohd Shahremy Ikmal Shahbudin. (2021). Kecenderungan nerotisme melalui karakteristik emosional dalam personaliti watak karya kreatif. Malay Literature, 34(1), 129-152. http:// doi.org. 10.37052/ml34(1)no7

\begin{tabular}{|c|c|c|c|c|c|c|c|}
\hline $\begin{array}{l}\text { Peroleh: } \\
\text { Received: }\end{array}$ & $13 / 2 / 2021$ & $\begin{array}{l}\text { Semakan: } \\
\text { Revised }\end{array}$ & $17 / 5 / 2021$ & $\begin{array}{l}\text { Terima: } \\
\text { Accepted: }\end{array}$ & $21 / 5 / 2021$ & $\begin{array}{l}\text { Terbit dalam talian: } \\
\text { Published online: }\end{array}$ & $3 / 6 / 2021$ \\
\hline
\end{tabular}

\footnotetext{
Abstrak

Penggemblengan watak dan perwatakan dalam penghasilan sesebuah novel merupakan elemen penting untuk memastikan penceritaan novel diterima oleh pembaca. Kajian ini bertujuan mengenal pasti kewujudan karekteristik emosional melalui kecenderungan neurotisme dalam pembentukan personaliti watak karya kreatif. Masalah pembinaan watak dan perwatakan sering wujud dalam karya sastera disebabkan penciptaan tidak dekat dengan kehidupan sebenar manusia. Karekteristik emosional dalam kecenderungan neurotisme berkaitan dengan emosi manusia dalam penulisan dan penyampaian. Oleh itu, novel Andai Itu Takdirnya (2008) karya Siti Rosmizah Ismail yang mendapat penilaian tinggi di laman web Goodreads.com dan menjadi fenomena dalam kalangan pembaca novel di Malaysia telah dipilih untuk dijadikan bahan kajian. Dalammenjalankan kajian ini, pertama sekali watak utama dalam novel ini dikenal pasti melalui naratif penceritaan. Kemudian, setiap watak utama dikelaskan berdasarkan kecenderungan emosional dalam karekteristik neurotisme melalui cirinya. Seterusnya, data dianalisis menggunakan teknik analisis kandungan bersama dengan Teori Big Five
}

(C) Dewan Bahasa dan Pustaka. 2021. This work is licensed under the term of the Creative Commons Attribution (CC BY) (http://creative commons.org/licenses/by/4.0/)

ISSN: 0128-1186 e-ISSN: 2682-8030 
Personality oleh McCrae dan Costa (1997) dan Model Lima Bahagian oleh Padesky (1986) yang digabungkan bersama untuk penyesuaian watak dan perwatakan. Berdasarkan analisis watak dalam novel yang dilakukan, pembentukan personaliti watak, dipengaruhi oleh ciri-ciri yang terdapat dalam model lima bahagian, iaitu yang terdiri daripada persekitaran, pemikiran, rasa hati, tingkah laku dan tindak balas perlu diterapkan dalam watak ciptaan pengarang. Hasil kajian ini dapat memberikan panduan kepada pengarang untuk membina personaliti watak dalam menghasilkan sebuah karya kreatif yang bernilai tinggi bagi memberikan kesan positif kepada pembaca.

Kata kunci: Personaliti, bahasa, Big Five Personality, remaja, neurotisisme

\begin{abstract}
The integration of character and characterization in the production of a novel is an important element to ensure the narration of the novel can be accepted by readers. This research aims to identify the existence of emotional characteristics through neurotic tendencies in the formation of a character's personality in creative works. The problem of character development and characterization always arises in literary works due to the dissimilarity between the fictional and real human life. Emotional characteristics in neurotic tendencies are related to human emotions in writing and presentation. Hence, the novel Andai Itu Takdirnya by Siti Rosmizah Ismail, which has received good reviews in the website Goodreads.com and has become a phenomenon among readers of novels in Malaysia, was chosen as the research material. To conduct this research, the main characters in the novel were first identified through the narrative. Then, every main character was classified based on neurotic tendencies in their emotional characteristics. Next, the data was analysed by using the content analysis method, through combining the Big Five Personality Theory and the Five-Part Model by Padesky (1986) and modifying it for character and characterization. Based on the analysis, the development of a character's personality, influenced by the characteristics stated in the Five-Part Model (environment, thought, feelings, actions, and response), has to be applied to characters created by the author. The results from this research can provide guidance for writers to develop character personality in order to produce creative worksof high value, to have a positive impact on readers.
\end{abstract}

Keywords: Personality, language, Big Five Personality Theory, adolescents, neuroticism 


\section{PENGENALAN}

Topik watak dan perwatakan dalam bidang kesusasteraan sering kali dibincangkan dan dikaji oleh pengkaji. Watak dan perwatakan dalam bidang kesusasteraan merupakan nadi utama yang menjadi medium penyampaian untuk diterima dan difahami oleh pembaca yang pelbagai latar belakang. Pada peringkat global dan dalam negara, pengkaji menyatakan bahawa watak dalam sesebuah karya merupakan penjelmaan manusia yang diolah untuk menjadikan sebuah penceritaan itu menarik untuk pembawakan plot seperti yang ingin disampaikan oleh pengkarya (Kamariah, 2014). Watak dalam sesebuah penceritaan mempunyai personaliti seperti manusia biasa (Saddock \& Ruiz, 2015). Allport (1960), menyatakan personaliti merupakan sebahagian psikologi tentang manusia yang dilahirkan secara kompleks dan saling melengkapi. Personaliti yang wujud dalam individu adalah sama ada bersesuaian dan tidak bersesuaian berdasarkan sifat yang dimilikinya itu (Gadbois, 2014). Personaliti dalam diri individu tidak dapat dipisahkan dan saling lengkap-melengkapi antara satu sama lain (Melanie \& Modecki, 2020). Individu yang berpersonaliti kebiasaannya dipengaruhi oleh emosi dalam hal membuat keputusan dan tindakannya.

Kepelbagaian emosi yang wujud ini membantunya untuk menzahirkan penyampaian agar diterima oleh individu lain supaya mudah difahami dan diterima (Zimmer-Gembeck, MJ, 2018). Dalam bidang kesusasteraan, emosi merupakan nadi utama untuk penyampaian mesej oleh pengkarya. Penulisan menerapkan mesej dan makna yang hendak disampaikannya untuk diketahui oleh pembaca. Mesej dan makna yang diterima dan difahami oleh pembaca menjadikan penceritaan menjadi lebih baik dan menarik.

Emosi merupakan sifat dalaman, iaitu perasaan yang wujud hasil tindak balas seseorang terhadap sesuatu perkara, pengalaman dan peristiwa yang berlaku. Contohnya adalah seperti rasa takut, marah kecewa, gembira, suka dan kasih sayang (Ekman \& Cordaro, 2011 dan Izard, 2009). Emosi sebagai reaksi balas terhadap situasi yang berlaku di sekeliling individu untuk membuat keputusan (Siti Hamim, \& Azianura Hani, 2012). Emosi diterjemahkan oleh individu dengan memperlihatkan reaksi diri terhadap penerima. Emosi yang diterjemahkan ini ialah respons terhadap persekitaran yang dilalui dan berlaku di sekelilingnya (Saddock \& Ruiz, 2015). Berdasarkan takrifan yang diberikan, dapat dikatakan bahawa emosi yang wujud dalam personaliti individu berkait rapat dalam perwatakan. Personaliti dalam karya pengarang melibatkan dialog yang digunakan, pengaruh daripada situasi, pengaruh melalui pemikiran. Kebiasaannya, pengarang menghasilkan personaliti perwatakan 
berdasarkan realiti hidup manusia yang sebenar (Gendron, Roberson, van der Vyver, \& Barrett, 2014; dan Hamza Alshenqeeti, 2016).

Dalam konteks personaliti individu, emosi memberikan kesan kepada perwatakan diri. Perwatakan ditakrifkan sebagai ciri-ciri atau sifat-sifat yang wujud dalam watak ciptaan yang menjadi tunjang penceritaan. Perwatakan juga menunjukkan pemikiran terhadap watak ciptaan pengarang. Secara khususnya, emosi dalam perwatakan yang dicipta berupaya memberikan kesan kepada individu lainnya. Emosi yang wujud ini memberikan kefahaman dan penerimaan yang berbeza oleh individu lainnya (Lavoie. \& Pychyl, 2001). Namun begitu, berbeza dalam penilaian personaliti individu melalui perwatakan dalam naratif penceritaan. Personalitiperwatakan yang diciptakan oleh pengarang dalam karya kreatif digarap untuk penghasilan penceritaan yang lebih menarik.

Dalam sesebuah naratif pembahagian watak dapat dibahagikan pembinaannya kepada dua aspek, iaitu watak utama dan watak sampingan. Watak dan perwatakan utama menjadi daya tarikan kepada pembaca. Perwatakan dalam sesebuah karya terbahagi kepada beberapa golongan, iaitu yang terdiri daripada perwatakan utama, perwatakan penting, perwatakan sampingan dan perwatakan latar. Watak dan perwatakan utama ialah watak yang diberikan perhatian dan tumpuan oleh pengarang dan menjadi tunjang penting dalam struktur penceritaan sesebuah karya berbanding dengan watakwatak lainnya. Keduanya, watak dan perwatakan yang kurang diberikan tumpuan dan perhatian oleh pengarang dalam struktur penceritaan berbanding dengan watak dan perwatakan utama. Ketiga, watak dan perwatakan latar yang kurang diberikan peranan dan tumpuan dalam struktur penceritaan berbanding dengan watak sampingan (Mohd Helmi \& Jamaluddin, 2018). Melalui penggolongan watak dan perwatakan ini, pengelasannya berdasarkan umur, kelas, pelajaran, jantina, sifat-sifat dan ciri-ciri menarik yang wujud dalam watak.

Penggolongan watak dan perwatakan perlulah mempunyai ciri-ciri seperti mudah difahami, menarik dan mengambarkan imej watak realiti dan lebih dekat dengan kehidupan sebenar seseorang manusia (Feldman, 2001). Penggolongan watak dan perwatakan berdasarkan kelas, iaitu dalam kumpulan watak manusia bawahan, pertengahan dan atasan. Watak dan perwatakan yang digolongkan dalam kumpulan yang disesuaikan dengan pekerjaan, usia dan ciri-ciri penampilan melalui personaliti watak perwatakan dalam struktur penceritaan berkenaan. Seterusnya, watak dan perwatakan berdasarkan jantina, iaitu pengelasan dibahagikan kepada golongan jantina lelaki dan wanita yang akan digambarkan dengan imej dan ciri-ciri yang lebih menarik untuk penjelasan watak perwatakan berkenaan. Dalam pengelasan 
watak dan perwatakan berdasarkan umur, sukar untuk disesuaikan dengan sifat-sifat watak kerana lumrahnya manusia mempunyai pelbagai perwatakan yang sukar untuk ditafsirkan. Pengelasan watak dan perwatakan ini menjadi daya penarik kepada pembaca dan membina kesempurnaan plot penceritaan yang lebih sempurna (Samsiah, 2012). Kewujudan watak dan perwatakan yang sempurna ini seterusnya membantu mencetuskan perasaan empati pembaca yang dapat memahami dan menyelami emosi watak (Palmer, 1991).

Kepentingan antara perwatakan dan emosi adalah saling berkait antara satu sama lain (Saddock \& Ruiz, 2015). Meskipun, perwatakan dicipta oleh penulis dalam karya rekaannya, penerimaannya oleh pembaca menjadi lebih jelas untuk difahami dan dihayati seterusnya menjadikan karya lebih menarik dan berkualiti. Perwatakan yang dihasilkan menggunakan bahasa untuk mengambarkan perlakuan dan sifat dalam dirinya untuk pembawakan watak yang diciptakan oleh pengarang dalam karya. Perlakuan dan sifat dizahirkan secara kompleks untuk mengambarkan tingkah laku manusia secara lahiriahnya. Perlakuan dan tingkah laku ini saling berhubung kait untuk diperlihatkan cerminan aspek diri kepada orang lain untuk difahami.

Perbincangan mengenai watak dan perwatakan dalam karya pengarang ini telah dibincangkan dalam kajian-kajian sastera di Malaysia. Mohd. Affandi (2017) menyatakan bahawa dunia kesusasteraan Malaysia memerlukan watak dan perwatakan yang kuat untuk memberikan kesan kepada pembaca. Kekuatan watak dan perwatakan diperkuat melalui penerapan aspek realiti sebenar kehidupan manusia di dalamnya (Ismail, 1988). Watak dan perwatakan dalam karya mempengaruhi pembaca dan membimbangkan sekiranya banyak watak negatif ditonjolkan dalam penulisan berkenaan (Ali, 1978). Watak dan perwatakan yang disampaikan menggunakan pelbagai teknik, iaitu secara langsung dan tidak langsung. Teknik secara langsung diperlihatkan dalam bentuk naratif penceritaan, manakala teknik tidak langsung diperlihatkan melalui penceritaan monolog dan imbas kembali. Penggunaan kedua-dua teknik ini turut memberikan kesan kepada pembaca melalui penerimaan dan pemahaman pembaca. Contohnya seperti dalam kajian perwatakan dalam karya novel indie di Malaysia menunjukkan keberkesanan watak dan perwatakan dalam karya berlandaskan kepada penggunaan gaya bahasa yang digunakan oleh pengarang dalam karya (Kamariah, 2014). Penggunaan gaya bahasa seperti slanga, dialek, dan hiperbola menjadikan kesan kepada watak dan perwatakan dalam karya memberikan kesan positif dan negatif untuk diterima oleh pembaca.

Seperti yang dijelaskan di atas, cabaran utama dalam watak dan perwatakan karya kreatif ciptaan pengarang adalah untuk memperlihatkan personaliti 
watak yang kompleks dan memberikan kesan positif untuk diterima oleh pembaca. Hal ini demikian kerana pembaca sasaran mungkin menerima watak dan perwatakan ciptaan pengarang secara terus. Selain itu, dalam konsep personaliti, kecenderungan personaliti neurotisme merupakan antara yang paling popular dan dirbincangkan melalui gaya penulisan (McCrae dan Costa, 1997). Watak dan perwatakan individu dalam personaliti neurotisisme ini menonjolkan dirinya dalam penulisan sebagai seorang yang menyendiri dan mempengaruhi diri individu lain (Ando \& Sakamoto, 2008).

Seterusnya, dilihat bahawa novel popular seringkali mendapat tempat dan perhatian para pembaca tanpa mengira peringkat usia. Watak dan perwatakan yang diciptakan oleh pengarang dalam karya kreatif ini dilihat menjadi ikutan dan perhatian pembaca. Kajian juga menyatakan bahawa watak dan perwatakan dalam karya kreatif popular lebih difahami oleh pembaca berbanding dengan karya sastera yang berat penyampaiannya (Palmer, 1991; Bibhu Datta Rout, 2017). Selain itu, penerapan emosi dalam naratif penceritaannya juga lebih mudah dihayati dan diterima oleh pembaca meskipun bersifat klise dalam penceritaannya (Samsiah, 2012).

Dengan mengambil kira watak dan perwatakan, emosi, personaliti dalam watak dan perwatakan karya kreatif, kajian ini meneliti karya kreatif popular, dengan memberikan fokus pada kecenderungan neurotisme melalui emosi dalam watak dan perwatakan melalui karya yang dihasilkan oleh pengarang popular.

\section{NEUROTISME DAN EMOSI}

Perkataan neurotisme ditakrifkan sebagai wujudnya emosi dalam diri yang mempengaruhi personaliti watak (McCrae \& Costa, 1997). Neurotisme merupakan salah satu daripada kecenderungan yang wujud dalam Teori psikologi Big Five Personality. Dalam teori ini, selain neurotisme terdapat empat lagi kecenderungan, iaitu extraversion, agreeableness, openness dan conscientiousness (McCrae \& Costa, 1997). Dalam teori psikologi, neurotisme mempunyai kecenderungan untuk membuat keputusan bergantung pada emosi dalaman dirinya sendiri, dan menghadapi kesukaran melalui penyelesaian yang dilaluinya. Namun demikian, berbeza melalui penulisan, kecenderungan neurotisme yang ditunjukkan melalui penulisan oleh individu dalam penyampaian emosi telah dikaji oleh pengkaji lepas. Antaranya termasuklah kajian oleh Lam dan Kamila (2014), yang membuktikan bahawa personaliti dan bahasa yang dihasilkan oleh individu digunakan dalam penulisan adalah berkaitan antara satu sama lain. Sifat diri dan kelakuan, merupakan asas 
kepada personaliti individu melalui penulisan yang digunakan oleh dirinya itu. Lazimnya, penulisan yang mewakili personaliti dirinya itu adalah sebagai pelambangan dirinya untuk diterima dan difahami. Begitu juga dalam kajian Siti Hamin dan Azianura Hani (2012), personaliti melalui penulisan merupakan pembentukan diri yang seterusnya memperlihatkan emosi diri dan persepsi individu. Emosi diri dan persepsi ini berlaku disebabkan oleh situasi dan pengaruh sekeliling yang mempengaruhi watak dan perwatakan.

Lavoie dan Pychl (2001) menyatakan pembentukan personaliti individu melalui penulisan menyebabkan berlakunya perubahan perwatakan yang memberikan kesan watak utama berdasarkan faktor dan pengaruh diri pengarang itu sendiri. Watak dan perwatakan menyebabkan berlakunya kecelaruan pengekalan personaliti diri watak yang disesuaikan sehinggakan merencatkan plot penceritaan. Situasi ini berlaku disebabkan oleh wujudnya emosi yang bertindak mempengaruhi perwatakan diri watak berkenaan dalam plot penceritaan yang pelbagai. Seperti yang dinyatakan oleh Mompean (2010) yang membuktikan melalui kajiannya bahawa emosi dalam watak dan perwatakan menyebabkan berlakunya interaksi yang tidak stabil disebabkan oleh pengaruh sifat positif dan negatifnya. Keadaan ini berlaku disebabkan oleh penyampaian dan penerimaan dalam komunikasi melalui ungkapan penceritaan dan dialog dalam naratif penceritaan yang digunakan (AmichaiHambuger, 2010).

Kecenderungan neurostime mempunyai perbezaan dengan kecenderungan lainnya yang terdapat dapat Teori Big Five Personality kerana kecenderungan neurotisme ini wujud dalam diri individu melalui penulisan (McCrae \& Costa, 1997). Melalui penulisan dalam novel, individu berkecenderungan neurotisme ini menonjolkan dirinya dengan cara berkomunikasi lebih tinggi dan diketahui oleh pembaca melalui penulisan yang dihasilkan dalam penceritaan. Watak dan perwatakan yang berkecenderungan neurotisme lebih memaparkan sifat negatif dalam penceritaan dan gaya komunikasinya dengan watak utama yang keduanya kerana interaksi yang wujud membantu dalam pembinaan plot penceritaan karya pengarang berkenaan (Samsiah, 2012).

Watak dan perwatakan seharusnya sistematik dan ditafsirkan dengan jelas bagi membolehkannya difahami (Nuhamizah, 2015). Namun begitu, terdapat juga kelemahan dalam pentafsiran watak dan perwatakan terutamanya yang melibatkan tanda, kod dan ketentuan yang lebih kompleks dalam penilaiannya. Sememangnya diakui, ciri-ciri utama dalam perwatakan adalah sukar untuk ditafsirkan dalam penulisan disebabkan oleh pemikiran pengarang yang dipengaruhi oleh emosi dalam penghasilannya (Kamariah, 2014) Namun begitu, hasil daripada proses pemantapan dan persepsi, penjelasan perwatakan 
menjadi lebih mudah difahami dan ditafsirkan oleh orang lain (Palmer, 1991). Pentafsiran watak dan perwatakan negatif memberikan kesan kepada pembaca dan tidak digalakkan dihasilkan oleh pengarang (Shahnon, 1979). Contohnya seperti penciptaan stereotaip terhasil disebabkan penghasilannya oleh penulis yang berbeza jantina dan menghasilkan watak dan perwatakan yang disubordinasikan, direndahtarafkan dan peminggiran aktiviti sebenar setiap jantina berkenaan (Samsiah, 2012). Contohnya seperti pengelasan watak perwatakan wanita berdasarkan kepada tiga golongan, iaitu gambaran watak wanita berasaskan kepada gender dan biologi, pemikiran wanita hanya untuk keperluan naluri manusia sahaja dan mempergunakan wanita untuk kepentingan kepada kaum lelaki. Akibatnya, terjadinya ketidakpuasan hati terhadap pengelasan ini dalam kalangan wanita yang membaca karya berkenaan (Bibhu Datta Rout, 2017).

Seterusnya, dalam kajian Fitri Palupi Kusumawati (2013) yang mengkaji mengenai personaliti utama dan faktor yang mempengaruhi karekter dalam plot penceritaan karya pengarang melalui novel. Melalui dapatan kajiannya, didapati bahawa wujudnya pengaruh dalaman dan luaran terhadap watak yang dibina oleh pengarang dan mempengaruhi plot penceritaan. Pengaruh dalaman melibatkan emosi yang wujud dalam diri individu secara lahiriah, iaitu sifat semula jadi, fizikal dan psikologi. Pengaruh luaran pula melibatkan pengaruh daripada keluarga, rakan di sekelilingnya. Karekter dalam watak dan perwatakan dapat dibahagikan kepada dua bahagian, iaitu karekter utama dan karekter sampingan. Pengelasan terhadap karekter watak perwatakan menggunakan teori personaliti yang diperkenalkan oleh Sigmund Freud. Teori personaliti Sigmund Freud ini mengelaskan kepada tiga bahagian yang terdiri daripada $i d$, ego dan superego. $I d$ merupakan tindakan yang dilakukan oleh watak untuk mencapai keinginannya. Keduanya, ego pula bermaksud penyelesaian masalah atau situasi yang terjadi dalam $I d$ sebelum ini. Penyelesaian melibatkan perancangan dan penelitian yang dilalui oleh watak utama dalam penceritaan. Ketiganya, ialah superego, yang merupakan kesan daripada penyelesaian yang diperoleh setelah bahagian id dan ego memberikan kesan positif kepada watak dan perwatakan. Hasil kajian yang sama turut dinyatakan oleh Oatley (2002), yang melihat bahawa psikologi mempengaruhi personaliti dalam perwatakan melalui aspek pemikiran dalaman dan luaran, iaitu yang membantu pembinaan pemikiran untuk penghayatan pembaca terhadap karya yang dipersembahkan. Begitu juga dalam watak dan perwatakan, pembinaan karekteriktik berdasarkan manusia sebenar adalah nadi utama yang menjadikan penceritaan lebih hidup dan dekat di hati pembaca (Samsiah, 2012). 
Seterusnya, Banicki (2017), mengkaji mengenai perbezaan karekter keperibadiaan dalam diri watak perwatakan. Dalam kajian pengkaji ini menunjukkan bahawa perbezaan personaliti individu melalui watak perwatakan ini adalah disebabkan oleh nilai keperibadian watak itu sendiri yang seterusnya menjadikan perwatakan bersistematik dalam penampilannya. Perwatakan yang bersistematik dihasilkan disebabkan oleh tindak balas dan rangsangan berdasarkan faktor karekter itu sendiri (Alfano, 2013). Miller (2013), juga menyatakan tindak balas yang terhasil menyebabkan personaliti individu mengalami perubahan dan menjadikan karekter individu lebih berperwatakan. Karekter individu yang berperwatakan ini menjadikan watak melengkapi psikologi yang seterusnya membentuk identiti dalam dalam dirinya. Dapatan yang sama telah dinyatakan oleh Ismail (1988) sebelum ini, iaitu dengan mengatakan bahawa percampuran antara konflik dan realiti sebenar manusia, menjadikan pengolahan perwatakan dalam karya lebih realistik.

Homiak (2015), menyatakan bahawa karekter dan personaliti saling berkait rapat antara satu sama lain kerana mempunyai evolusi makna yang diterjemahkan kepada orang lain untuk difahami. Karekter dan personaliti mempunyai kontak dengan aspek perilaku manusia yang seterusnya menghasilkan sifat tersendiri yang membantu pembentukan evolusi. Aspek perilaku watak perwatakan ini membantu dalam menyaring pengaruh sifat positif dan sifat negatif yang sentiasa berada di sekeliling. Sifat positif dan negatif yang wujud dalam diri watak perwatakan perlulah seimbang kerana sekiranya tiada keseimbangan menyebabkan personaliti berada dalam keadaan tidak stabil (Woolfolk, 2002). Ketidakseimbangan personaliti melalui watak perwatakan ini disebabkan oleh penggunaan bahasa untuk pembentukan karekter dan juga melalui bahasa untuk pembentukan personaliti. Kajian oleh Brinkmann (2010), pembentukan karekter dan personaliti ini merupakan proses yang kompleks sama ada dalam bentuk realiti atau pun gambaran penceritaan. Proses yang kompleks ini terjadi disebabkan oleh budaya keperibadian individu manusia itu sendiri untuk dinilai dan dipersembahkan. Berbeza dalam kajian Maclyntyre (2013), yang menyatakan bahawa kemurniaan karekter individu yang positif perlulah seiring dengan sifat dan diri manusia yang sebenarnya. Kemurniaan karekter berdasarkan kepada keperluan karekter untuk penyesuaian dalam pembentukan sosial untuk membina perwatakan dirinya.

Kristjannsson (2012), menyatakan pembinaan karekter membantu membentuk keperibadian dan perkembangan personaliti watak berdasarkan kepada dua aspek, iaitu melalui ciri-ciri dan sifat umum diri manusia secara 
realitinya dan perbezaan dalam diri manusia antara satu sama lain. Pembinaan karekter dalam keperibadian merupakan aspek utama dalam perbezaan penilaian antara individu melalui personaliti diri yang dimilikinya. Menurut Goldie (2004), ciri-ciri dalam watak dan perwatakan mempunyai nilai sifat keperibadian berdasarkan kepada moral yang dimiliki oleh dirinya sendiri.

Seperti yang dinyatakan oleh Padesky dan Mooney (1990) sebelum ini, perubahan yang dilalui oleh watak dan perwatakan dalam pembentukan personaliti terhasil melalui pengalaman yang dilalui oleh watak berkenaan. Pengalaman kehidupan dibahagikan kepada empat bahagian, iaitu persekitaran, pemikiran, rasa hati, tingkah laku dan tindak balas fizikal. Keempat-empat bahagian ini saling berkaitan antara satu sama lain dan saling memerlukan untuk pembentukan personaliti diri watak individu. Pandangan yang sama turut dinyatakan oleh Nor Raudah (2006), iaitu personaliti diri watak sentiasa berkembang dan berubah-ubah melalui perilaku dan tindakannya.

Dengan mengambil kira tinjauan ini, kajian ini akan (1) mengenal pasti kecenderungan neurotisme dalam watak perwatakan sebuah karya kreatif popular di Malaysia yang menjadi fenomena dalam kalangan peminat novel di Malaysia, dan seterusnya (2) menghuraikan pengaruh karekteristik dalam pembentukan personaliti watak dan perwatakan dalam karya kreatif popular berkenaan berdasarkan kecenderungan neurotisme.

\section{METODOLOGI KAJIAN}

Kajian kualitatif ini menggunakan sebuah novel kreatif popular hasil karya Siti Rosmizah Ismail yang bertajuk Andai itu Takdirnya yang diterbitkan oleh Buku Prima Sdn Bhd pada tahun 2007. Novel ini telah mencatatkan jualan tertinggi di Malaysia dan telah diulang cetak sebanyak 15 kali cetakan. Idea penulisan novel ini tercetus setelah pengarangnya bermimpi perjalanan cerita berkenaan yang kemudiannya diterjemahkan dalam bentuk penceritaan novel. Berdasarkan data jualan yang diterima daripada Buku Prima Sdn Bhd, novel ini telah terjual melebihi 100000 buah dan masih terjual dan mendapat permintaan sehingga kini. Novel ini dipilih kerana mendapat penilaian dan komen tinggi lebih 90 peratus di laman web Goodreads.com.

Untuk mengenal pasti kecenderungan neurotisme dalam penulisan pengarang, kajian ini memanfaatkan teori personaliti big five yang diperkenalkan oleh McCrae dan Costa (1997), iaitu melalui kecenderungan neurotisme yang merupakan sebahagian daripada lima kecenderungan yag terdapat dalam teori bigfive personality. Kecenderungan neurotisme dipilih, kerana kecenderungan ini paling popular dikaji berbanding dengan empat kecenderungan personaliti 
yang lain dalam teori personality Big Five personality berkaitan (Sailing \& Phillipis, 2010). Dalam kecenderungan neurotisme, ciri-ciri karekteristiknya terdiri daripada emosional, kebimbangan, berpuas hati, selesa, cekal dan simpati. Namun begitu, dalam kajian ini pengkaji hanya memfokuskan kepada karekteristik emosional sahaja untuk melihat watak dan perwatakan dalam plot penceritaan novel ini bagi setiap bab dalam novel ini disebabkan kerana penilaian yang diberikan dalam data laman web goodreads menyatakan yang watak dan perwatakan dalam novel ini yang menjadikan penceritaannya menarik dan mempunyai kelainan serta mempunyai pelbagai emosi bagi setiap perwatakannya. Novel ini mengandungi 58 bab dan halaman muka suratnya berjumlah 583. Karekteristik emosional juga dilihat antara faktor utama kejayaan novel ini kerana watak dan perwatakan utama dalam novel ini memaparkan pelbagai emosi sebagai tarikan penceritaan berdasarkan plot penceritaannya.

Pertamanya, watak dalam penceritaan novel dikelaskan kepada watak utama, watak sokongan dan watak sampingan. Watak utama dikelaskan sebagai watak yang menjadi kekuatan penceritaan manakala watak sokongan dan watak sampingan dikelaskan sebagai penyokong kepada pembawakan watak dan perwatakan dalam naratif penceritaan. Seterusnya, setelah watak utama dikelaskan, pengkaji mengelaskan situasi dan naratif yang hanya berkaitan dengan karekteristik emosional sahaja berdasarkan kepada ciri neurotisme. Penyelidik memasukkan setiap naratif ini dalam perisian NVivo. Naratif dikelaskan dalam teks novel ini berdasarkan ciri-ciri karekteristik neurotisme. Perisian NVivo dipilih kerana memudahkan penyelidik mengelaskan dan membahagikan setiap analisis dan dapatan yang diperoleh dalam pembacaan novel ini sepanjang kajian dilakukan. Dapatan diperoleh melalui pengelasan watak dan perwatakan serta naratif penceritaan. Berdasarkan watak dalam novel ini, pengkaji mendapati terdapat dua watak utama, iaitu watak utama lelaki dan watak utama wanita berdasarkan ketetapan oleh penulis novel itu sendiri yang dinyatakan dalam karyanya.

Setelah karekteristik emosional dikenal pasti melalui penyenaraian berdasarkan ciri-ciri dalan neurotisme, seterusnya pengkaji menggunakan teknik analisis kandungan untuk menganalisis setiap ayat yang digunakan oleh kedua watak utama melalui teks dan dialog dalam teks. Berdasarkan karekteristik emosional yang telah dikenal pasti, pengkaji seterusnya menggunakan model lima bahagian yang terdiri daripada persekitaran, pemikiran, rasa hati, tingkah laku dan tindak balas fizikal yang disesuaikan dengan karekteristik emosional dalam bentuk jadual untuk gambaran kajian yang lebih jelas terbentuknya personaliti. Melalui pemikiran pengarang, pengkaji melihat naratif penceritaan 
melalui watak dan perwatakan utama. Pemikiran dalam perwatakan dinilai dan dianalisis melalui gaya bahasa dialog yang dipertuturkan oleh watak utama ketika berkomunikasi dengan watak sampingan yang lain. Pemikiran dibahagikan kepada dua, iaitu positif dan negatif (Paldesky, 2001).

Keduanya, rasa hati merupakan sikap dan diri perwatakan yang wujud dalam pembawakan naratif penceritaan (Ali, 1978). Rasa hati terdiri daripada perasaan watak yang diwujudkan untuk penyampaian komunikasi dengan watak lainnya. Rasa hati dianalisis melalui gaya bahasa yang digunakan dan maklum balas penerima terhadap penyampaian watak dalam komunikasi. Ketiga, ialah tingkah laku watak perwatakan dalam membawakan plot penceritaan karya pengarang untuk difahami oleh pembaca melalui gambaran pembaca. Tingkah laku watak dianalisis berdasarkan ketetapan oleh pengkaji, iaitu yang bersesuaian dengan karekteristik neurotisme. Keempat, ialah tindak balas fizikal, iaitu berdasarkan naratif penceritaan dan situasi yang berlaku terhadap watak utama dan watak sampingan. Tindak balas ini berlaku melalui hubungan komunikasi dalam naratif penceritaan. Karekteristik emosional dipaparkan dalam Rajah 1.

Berdasarkan Rajah 1, pengkaji menunjukkan pembentukan personaliti dalam perwatakan. Teks yang dianalisis dilabelkan oleh pengkaji, supaya mudah difahami oleh pembaca. Analisis kandungan dalam kajian ini dimulakan oleh pengkaji dengan membaca keseluruhan novel dan memahami penceritaan yang disampaikan oleh pengarang dalam karyanya ini. Teks yang diperoleh disesuaikan dengan ciri-ciri yang dinyatakan oleh McCrae dan Costa (1999), Seterusnya, pengkaji menganalis dan membincangkan dapatan yang diperoleh.

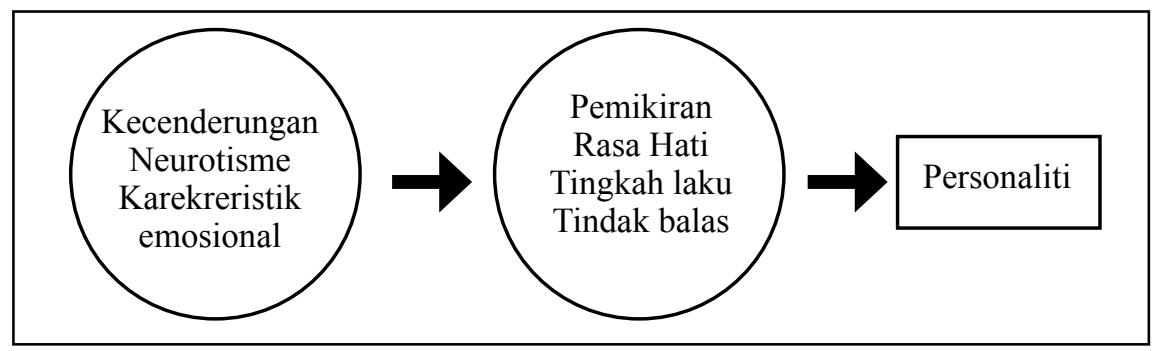

Rajah 1 Proses pembentukan personaliti watak karya kreatif. 


\section{ANALISIS DAN DAPATAN KAJIAN}

Dalam kajian ini, terdapat dua watak utama dalam plot penceritaan, iaitu yang dinamakan sebagai Syed Adam Aizril bin Syed Abbas (W1) dan watak utama kedua ialah Aleya (W2) yang diperoleh melalui makluman penulis di dalam novel ini berdasarkan tinjaun perbualan antara penulis dan pembaca novel ini di laman media sosial penulis. Hasil analisis, Rajah 1 di bawah menunjukkan perwatakan kedua-dua watak utama.

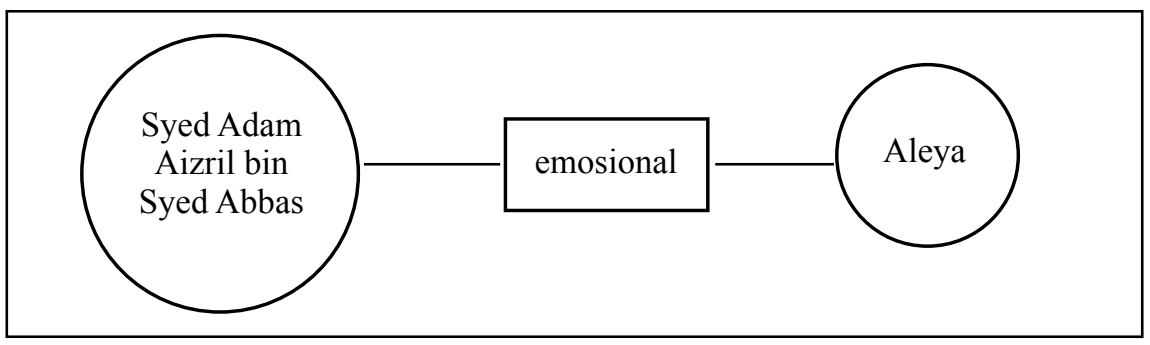

Rajah 2 Hubungan antara watak dan karekteristik emosional.

Berdasarkan Rajah 2, analisis dilakukan dalam naratif penceritaan antara kedua-dua watak utama untuk kesemua 58 bab untuk W1 dan W2. Penentuan W1 dan W2 dibuat berdasarkan pengarang (narrator novel), iaitu dengan memastikan bahawa kedua-dua watak ini wujud pada setiap bab dalam penceritaan. W1 merupakan watak utama kerana peranannya sebagai tunjang utama plot penceritaan bersama dengan W2. Selain itu, W1 dan W2 merupakan

Jadual 1 Analisis watak utama keseluruhan bab novel.

\begin{tabular}{|c|c|c|}
\hline Sifat Watak & W1 & W2 \\
\hline positif & Penyayang & Penyayang \\
& Cinta & Pemurah \\
& Simpati & Penyabar \\
& Rasa bersalah & Pendiam \\
& Pemarah & Mudah ditindas \\
negatif & Syak wasangka & Tiada keyakinan \\
& Cemburu & diri \\
& Pendendam & sensitif \\
& Mudah & \\
& terpengaruh & \\
\hline
\end{tabular}


pelengkap naratif penceritaan utama yang membantu perkembangan plot-plot penceritaan yang direka oleh pengarang. Watak W1 dan W2, mempunyai perkaitan antara satu sama lain, dan saling berhubungan dalam setiap babak penceritaan novel ini. Watak W1 dan W2 menjadi pencetus kepada watak sampingan dan watak dorongan yang lain. Jadual 1 menunjukkan analisis perwatakan untuk W1 dan W2 dalam keseluruhan novel ini.

Dalam analisis Jadual 1 yang dipaparkan, karekteristik emosional dibahagikan kepada dua bahagian, iaitu sifat positif dan sifat negatif. Keduadua sifat positif dan negatif ini diperoleh oleh pengkaji melalui analisis terhadap 58 bab di dalam novel ini. Analisis dilakukan melalui pembacaan dan penyesuain teks dalam novel yang kemudiannya disesuaikan dengan ciri kecenderungan neurotisme. Dalam W1, sebanyak empat sifat emosional yang wujud, iaitu penyayang, cinta, kasihan dan simpati.

Emosi pertama, iaitu penyayang dilihat wujud dalam W1 terutamanya melalui hubungannya dengan keluarga terdekat dan orang yang baru dikenalinya. Hubungan bersama dengan keluarga terdekat W1, wujud disebabkan W1 merupakan anak yang menjadi harapan keluarga dan menjadi tunjang utama dalam menguruskan kerjaya milik ahli keluarganya. Selain itu, emosi penyayang juga wujud dalam hubungan bersama dengan orang yang baru dikenalinya, iaitu bersama dengan W2 melalui kaitan hubungan dan perkaitan antara kedua-dua watak dalam naratif penceritaan. Hubungan bersama dengan W2 dan W1 ini bermula dengan plot sebagai orang yang tidak mengenali, dikenali dan kemudiannya berakhir dengan hubungan sebagai suami isteri. Emosi penyayang ini juga berkait rapat dengan emosi cinta. Dalam W1, emosi cinta ini dilihat wujud bersama-sama dengan ahli keluarganya yang terdekat, rakan yang baru dikenalinya, isteri dan juga anaknya. Namun demikian, emosi cinta dalam W1, tidak kekal dan stabil disebabkan oleh pengaruh sekelilingnya.

Emosi simpati yang wujud dalam diri W1, iaitu sifat ingin membantu dan memudahkan uruskan hal orang lain. Analisis menunjukkan W1, mudah simpati dengan orang terdekat dengannya seperti rakan sekerja, rakan baiknya, ahli keluarga dan juga bersama dengan W2.

Emosi rasa bersalah yang wujud dalam diri W1. Sifat bersalah ini wujud disebabkan W1 menyedari setiap perkara yang dilakukannya bertentangan dengan keinginan yang dimahukan olehnya. Namun demikian, dilihat daripada naratif penceritaan, emosi rasa bersalah W1 hanya wujud setelah dia melakukan perkara yang menindas individu lain sama ada melalui perlakuan atau perilaku yang memberikan kesan yang ketara. Emosi rasa bersalah dalam W1 wujud melalui tindak balas terhadap W2, yang menyebabkan W1 mengalami penyesalan dan berbaik semula dengan watak lain yang 
berdekatan dengannya.

Seterusnya, untuk W2, sebanyak empat emosi dilihat wujud, iaitu yang pertama ialah emosi penyayang. Emosi penyayang untuk W2, dilihat lebih stabil dan wujud bersama-sama dengan orang terdekat dengannya melalui percakapan dan perbuatan yang berterusan dan berulang. Dalam plot penceritaan, emosi penyayang sentiasa wujud terutamanya ketika W2, menghadapi situasi dan persekitaran yang memberikan kesan kepada W2. Emosi kedua, iaitu emosi pemurah yang wujud dalam diri W2 terutamanya yang melibatkan hal kewangan, sering membantu watak sampingan lain untuk menyelesaikan permasalahan yang dihadapi. Dalam emosi penyabar, W2 dilihat cenderung untuk menyelesaikan setiap permasalahan yang dihadapi terhadap dirinya. Emosi penyabar ini dilihat wujud dalam permasalahan bersama-sama dengan W1, yang menjadi plot utama penceritaan dan pencetus konflik yang menonjolkan perwatakan W2. Emosi penyabar dilihat ketara wujud dalam W2 terutamanya dalam menghadapi masalah hubungan rumahtangganya bersama dengan W1. Emosi diri W2 yang pendiam juga wujud terutamanya dalam bertindak balas terhadap W1, yang memberikan respons positif dan negatif serta mempengaruhi tindak balas oleh W2. Emosi pendiam yang wujud dalam diri W2 adalah sebagai respons terhadap perwatakan dirinya yang sebenar, iaitu menunjukkan ketabahan dan perilaku dirinya sebagai seorang wanita yang cekal dan tabah menghadapi kesukaran dalam kehidupannya. Hal ini ditunjukkan oleh W2 melalui tindakannya berdiam diri dan memendam perasaan meskipun berada dalam keadaan dirinya yang tidak stabil

Seterusnya, dalam kareteristik emosional bersifat negatif, analisis emosi dalam W1 yang wujud adalah seperti pemarah. Emosi pemarah W1, menunjukkan sifat keegoan kerana status dirinya yang bekerjaya, berkuasa dan berasakan kehebatan dirinya berbanding dengan individu lain. Selain itu, emosional W1 juga mempunyai emosi syak wasangka, iaitu mempunyai anggapan negatif terhadap individu sekelilingnya, termasuklah W2. Watak W1 mempuyai sifat prasangka dan mudah membuat telahan terhadap W2 melalui situasi dan pengaruh individu sekelilingnya. Kesan anggapan syak wasangka ini menyebabkan wujudnya tindak balas yang memberikan kesan terhadap watak lain dalam plot penceritaan. Selain itu, analisis juga menunjukkan emosi syak wasangka merupakan plot konflik utama yang terjadi antara W1 dan W2. Antara kesan yang wujud akibat emosi syak wasangka, menyebabkan terjadinya emosi cemburu oleh W1 terhadap individu lain, termasuklah W2. Emosi cemburu berlaku terhadap W1 disebabkan oleh rasa tidak puas hati dan mencabar kemahuan dan keinginan dirinya secara langsung atau tidak langsung. Berdasarkan plot penceritaan, analisis menunjukkan yang W1 mudah 
bertindak disebabkan oleh pengaruh daripada emosi cemburunya itu. Emosi cemburu dalam W1 berlalu disebabkan rasa sayang dan prasangka dalam diri watak W1. Seterusnya, akibat emosi syak wasangka dan emosi cemburu menyebabkan terhasilnya emosi pendendam. Emosi pendendam berlaku disebabkan kemahuan dan kehendak W1 untuk memberikan kepuasan kepada dirinya. Kepuasan dan kehendak yang dimahukan oleh W1, menyebabkan watak terdekat dengannya seperti W2, dan watak sampingan yang lain menerima kesannya. Selain itu, W1 juga mudah terpengaruh dengan watak yang rapat dengannya sehingga menyebabkan W1 membuat keputusannya sendiri tanpa mengambil kira sesuatu perkara itu positif atau negatif. Analisis menunjukkan emosi mudah terpengaruh ini berlaku disebabkan oleh dua faktor utama, iaitu faktor sekeliling dan faktor dirinya sendiri. Faktor sekeliling disebabkan oleh individu yang terdekat dengannya, yang mengenali W1 dan mengenali W2 dengan lebih dekat lagi. Faktor dirinya pula berlaku disebabkan oleh pengaruh emosi dalaman yang menyebabkan terjadinya tindakan untuk penyelesaian.

Berbeza dengan W2, analisis menunjukkan tiga emosi negatifnya yang ketara dalam plot penceritaan. Pertamanya, emosi negatif W2, iaitu mudah ditindas oleh individu lain. W2 dilihat berlembut dengan segala dugaan yang dihadapinya meskipun dia cuba mencari penyelesaian untuk mengatasi permasalahan yang dilaluinya. Oleh sebab sikap W2 yang berlembut, wujudnya pula emosi dalam dirinya sendiri, iaitu tidak mempunyai keyakinan diri untuk membuat keputusan meskipun berpihak kepada dirinya. Emosi ketiga yang wujud dalam W2 ialah emosi sensitif. Analisis menunjukkan yang emosi sensitif berlaku disebabkan oleh kelemahan dalam diri W2 itu sendiri. Keadaan ini berlaku disebabkan W2 sering ditindas oleh W1 sehinggakan W2 berbelah bahagi untuk membuat keputusannya sendiri.

\section{Pembentukan Personaliti}

Pembentukan personaliti watak perwatakan dalam karya kreatif, iaitu novel Andai Itu Takdirnya ini terbentuk hasil daripada plot penceritaan berlandaskan karekteristik emosional yang dihasilkan oleh pengarang berdasarkan fantasi dan khayalan yang dilalui oleh dirinya sendiri. Pembentukan personaliti ini menjadi tarikan kepada plot penceritaan di samping bertindak sebagai medium penyampaian mesej kepada pembaca. Tarikan kepada plot melibatkan penyusunan plot dan gabungan watak bersama dengan perwatakan yang membawa keseluruhan penceritaan. Pembentukan personaliti yang dihasilkan membantu meningkatkan kefahaman pembaca terhadap penceritaan. Analisis yang menggunakan model lima bahagian, yang terdiri daripada persekitaran, 
pemikiran, rasa hati, tingkah laku dan tindak balas sebelum terhasilnya personaliti individu. Analisis menunjukkan contoh teks yang dipilih secara rawak dan perkaitannya dalam pembentukan personaliti.

\section{Pengaruh Persekitaran}

Pengaruh persekitaran terhadap watak dan perwataan W1 dan W2, disebabkan oleh persekitaran yang diwujudkan oleh pengarang untuk menjadikan plot penceritaan lebih bervariasi dan bersesuaian dengan situasi.

\section{Contoh 1}

Teks sumber : Aleeya (W2?) tiba di Lapangan Terbang

Antarabangsa Kuala Lumpur (KLIA) Sepang, tepat jam 6.00 petang. Dari jauh Aleya sudah nampak Encik Idris dan Pak Su Idham. Dengan tergesa-gesa Aleya menolak laju bagasi di dalam troli untuk mendapatkan ayahnya. Prang! Aleya terlanggar seorang lelaki (W1) sehingga hadiah yang berada di tangan lelaki itu terjatuh. (Bab $1: 1$ )

Analisis : $\quad$ Teks sumber contoh 1, persekitaran mempengaruhi tindakan W1 sehingga mencetuskan kemarahan akibat daripada perilaku W2. W1 bertindak balas terhadap situasi spontan yang berlaku. Dalam plot penceritaan, persekitaran awal ini menjadi permulaan konflik pertemuan antara W1 dan W2. W1 bertindak untuk mengenali W2, setelah berlakunya situasi.

Berdasarkan contoh 1, menunjukkan bahawa pengaruh persekitaran telah menyebabkan perwatakan antara W1 dan W2 berubah daripada sifat awal dirinya. Pengaruh persekitaran dalam contoh 1 ini wujud disebabkan oleh aspek pertemuan secara kebetulan, situasi yang menjadi penyebab kepada pertemuan antara watak W1 dan W2 sehingga mencetuskan konflik kepada plot penceritaan. Situasi secara tidak langsung, iaitu keadaan pertemuan antara W1 dan W2 berdasarkan situasi ini telah menyebabkan W1 bertindak balas terhadap keadaan yang berlaku.

\section{Pengaruh Rasa Hati}

Pengaruh rasa hati berlaku terhadap watak perwatakan W1 dan W2, disebabkan oleh pengaruh individu lain yang bersama-sama dengan kedua-dua watak 
dalam hal membuat keputusan untuk kepentingan dirinya sendiri. Pengaruh rasa hati merangkumi perasaan dalaman dan luaran oleh W1 dan W2 yang dirasai dan ditunjukkan melalui tindakan dan perlakuan oleh kedua mereka.

\section{Contoh 2}

Teks sumber : Hakikatnya, memang Aleya (W2) terasa. Dia tidak nampak atas alasan apa suaminya meninggalkan dirinya sendirian. Tidak salah kalau Syed Aizril ingin memperkenalkan dirinya pada rakan-rakan niaganya yang lain. (Bab 28:264)

Analisis : $\quad$ Tek sumber contoh 2 rasa hati memperlihatkan watak W2 (Aleya), meluahkan perasaan dalaman dirinya terhadap orang sekelilingnya. Kesannya, W2 terkesan disebabkan konflik yang terjadi kepadanya dan mempengaruhi emosi dirinya dengan apa yang berlaku.

Berdasarkan contoh 2, menunjukkan pengaruh rasa hati terhadap watak dan perwatakan. Rasa hati wujud melalui perasaan dalaman dan luaran dan hanya diketahui oleh diri watak itu sendiri sahaja. Perasaan dalaman menyebabkan berlakunya konflik terhadap diri watak dan mendorong melakukan tindakan balas tanpa kawalan, contohnya seperti emosi dan reaksi yang memberikan kesan kepada watak lain dalam penceritaan. Akibatnya, berlaku pelbagai lagi konflik dan menjadikan plot lebih variasi.

\section{Pengaruh Tingkah Laku}

Pengaruh tingkah laku berlaku melalui tindakan yang dilakukan oleh watak disebabkan oleh kemahuan dan kehendak bagi memenuhi kepuasan dirinya sendiri. Selain itu, tingkah laku juga merupakan paparan imej sebenar watak untuk dinilai dan difahami oleh individu lain.

\section{Contoh 3}

Teks sumber : Petang itu sebaik sahaja Aleya turun dari teksi, dia melihat Syed Aizril sedang duduk di taman sambil menikmati minuman petang. Sebaik sahaja dia melalui taman itu, dia dapat melihat Syed Aizril merenungnya tanpa berkelip dan wajahnya masam mencuka. (Bab 11:97) 
Analisis : $\quad$ Teks sumber contoh 3 menunjukkan yang watak Syed Aizril menunjukkan perasaan marahnya melalui reaksi tubuh badannya dia mudah difahami oleh W2 (Aleya).

Berdasarkan contoh 3 , reaksi tingkah lalu berupaya menyampaikan perasaan dalaman dirinya untuk difahami oleh individu lain tanpa adanya komunikasi melalui pertuturan. Watak yang memahami maksud tingkah laku individu lain mentafsirkan makna berkenaan untuk difahaminya. Pentafsiran makna ini melibatkan andaian terhadap situasi dan konflik yang sedang dialaminya tanpa pengaruh daripada sekeliling dan individu lain. Pentafsiran makna oleh watak ini menyebabkan plot penceritaan lebih berfokus dan mengelakkan berlakunya kebosanan dalam kalangan pembaca.

\section{Pengaruh Tindak Balas Fizikal}

Pengaruh tindak balas fizikal berlaku melalui tindakan watak yang agresif sehingga memberikan kesan kepada individu lain. Akibat daripada pengaruh tindak balas fizikal ini menyebabkan gangguan emosi kepada watak yang melakukan dan menerima akibatnya.

\section{Contoh 4}

Teks sumber : $\quad$ Tangan Syed Aizril diraih tapi secepat itu disentap semula oleh isterinya. Terkedu Aleya dibuatnya. Syed Aizril terus memusing badannya memandang Aleya dengan wajah yang serius. Jari telunjuknya tepat pada muka Aleya. (Bab $35: 345)$.

Analisis Teks sumber contoh 4, menunjukkan perlakuan W1 terhadap W2 melalui tindak balas fizikal untuk menunjukkan emosi dalaman dirinya. Emosi melalui tindak balas fizikal ini berlaku secara sengaja atau tidak disengajakan.

Berdasarkan contoh 4, menunjukkan bahawa pengaruh tindak balas fizikal yang berlaku secara sengaja atau tidak sengaja. Emosi negatif biasanya terjadi akibat daripada pengaruh tindak balas fizikal ini. Dalam contoh 4, dilihat W1 menggunakan anggota fizikal dan reaksi fizikal badan bagi menyampaikan emosi dalaman dirinya. Akibat tindakan W1 menyebabkan wujudnya pandangan negatif terhadap W1 yang mempengaruhi emosi pembaca secara langsung. 


\section{Personaliti Watak dan Perwatakan}

Berdasarkan analisis melalui karekteristik emosional dalam kecenderungan personaliti serta model lima bahagian, dilihat bahawa pengarang menjadikan dua aspek ini, iaitu emosi dan personaliti sebagai asas utama dalam perkembangan plot penceritaan. Personaliti perwatakan dalam penceritaan novel ini dimulakan dengan konflik awal, iaitu pengenalan watak. Pengenalan watak antara W1 dan W2, dimulakan dengan pertemuan awal sebelum kedua-duanya berkomunikasi dan menjadi latar dalam plot penceritaan awal. Dalam plot penceritaan awal ini, pengenalan watak utama dan watak sampingan diperkenalkan oleh pengarang untuk menjelaskan kepada pembaca pembawakan setiap perwatakan sepanjang pembacaan karya novel ini. Proses pengenalan awal watak dan perwatakan ini penting bagi memberikan tafsiran awal kepada pembaca personaliti watak dalam plot penceritaan yang sebenarnya. Pentafsiran awal oleh pembaca membantu dalam perkembangan watak utama dan watak lainnya untuk terus kekal dalam plot penceritaan dan dihayati dengan baik oleh pembaca.

Analisis melalui watak perwatakan W1 yang dijalankan sebelum ini menunjukkan sifat negatif dan kemudiannya berakhir dengan sifat positif dalam plot penceritaan. Sifat negatif yang ditunjukkan oleh W1 seterusnya diselesaikan sendiri oleh watak berkenaan pada akhir plot penceritaan dan memberikan kesan yang positif seperti hubungan komunikasi untuk dinilai sendiri oleh pembaca. Personaliti W1 terbahagi kepada tiga bahagian, iaitu awalan, pertengahan dan pengakhiran. Pada peringat awalan, personaliti pewatakan ditunjukkan sebagai seorang lelaki yang hebat dengan kerjayanya, penampilannya dan gaya kehidupannya yang bebas. Seterusnya, pada peringkat pertengahan personaliti W1 menunjukkan personaliti W1 mula berkembang dan berubah perwatakannya disebabkan oleh pengaruh persekitaran dan individu yang terdekat dengannya. Personalitinya menjadi setara, iaitu antara positf dan negatif. Personaliti dalam pengaruh pertengahan juga berlaku juga disebabkan oleh konflik dalaman diri yang dialami oleh watak dalam penceritaan novel. Konflik dalaman diri oleh watak merangkumi penyelesaian dan pemikiran dalam penentuan sifatnya sama ada positif dan negatif, Seterusnya, yang ketiga pengakhiran yang menunjukkan rangkuman personaliti watak W1 secara keseluruhannya. Melalui personaliti pengakhiran ini, ditunjukkan perilaku W1 setelah menerima kesan daripada personaliti awalan dan pertengahan sebelum ini. Kesan yang diterima W1 menyebabkan dirinya berubah untuk menjadi watak dan perwatakan yang lebih positif. 


\section{PERBINCANGAN}

Cabaran utama yang dihadapi oleh penulis kreatif ialah menghasilkan sebuah karya yang difahami dan diterima baik oleh pembaca. Penyampaian melalui karya kreatif perlulah lengkap, iaitu penceritaan yang baik, gaya bahasa, watak dan perwatakan yang menarik untuk diterima dan difahami oleh pembaca. Kajian ini dilakukan untuk mengenal pasti personaliti watak dalam penulisan kreatif dan seterusnya mengkaji perwatakan melalui karekteristik yang dihasilkan oleh penulis untuk menjadikan karya kreatif mereka menarik dan bermesej untuk diterima dan difahami oleh pembaca. Kajian terdahulu tentang watak dalam karya kreatif menunjukkan bahawa perwatakan perlulah seiring dalam penceritaan. Perwatakan yang mempunyai sifat positif dan negatif memberikan impak dan nilai yang tinggi kepada sesebuah karya. Kajian terdahulu mendapati perwatakan hanya menunjukkan penciptaan watak seiring dengan plot penceritaan. Namun begitu, dalam kajian ini, pengkaji mendapati bahawa penciptaan watak dan perwatakan haruslah berdasarkan personaliti manusia yang sebenar supaya lebih dekat dan difahami oleh pembaca.

Proses mengenal pasti personaliti watak ini terhasil melalui penerapan emosi dalam penulisan karya kreatif. Emosi dalam penulisan kreatif merupakan aspek penting dalam plot penceritaan supaya pembaca terkesan dengan penyampaian oleh pengarang. Dalam kajian ini, pengkaji hanya menggunakan emosi emosional dalam karekteristik. Emosi emosional merupakan emosi yang paling banyak wujud dalam plot penceritaan novel berbanding dengan emosi lain dalam kajian personaliti. Emosi emosional juga merupakan antara ciri-ciri yang wujud dalam pembentukan personaliti yang seterusnya mempengaruhi penggunaan dialog dan pembinaan plot penceritaan yang baharu (Rohayati, Tengu Intan Marlina \& Madiawati, 2018). Emosi emosional merupakan salah satu karekteristik yang terdapat dalam ciri-ciri kecenderungan neurotisme. Selain karekteristik emosional ini, neurotisisme juga mempunyai ciri-ciri lain, iaitu terdiri daripada rasa bersalah, bertindak tidak rasional, dan keperibadian.

\section{KESIMPULAN}

Berdasarkan kajian yang telah dijalankan ini, personaliti perwatakan yang wujud dipengaruhi oleh situasi dan persekitaran dilalui oleh watak. Situasi dan persekitaran membantu memberikan kefahaman kepada pembaca untuk membayangkan keadaan yang dilalui oleh watak dalam plot penceritaan. Kajian ini menunjukkan bahawa penerapan emosi dalam pembentukan personaliti perwatakan membantu penyampaian dan pembinaan plot penceritaan menjadikannya lebih menarik dan dramatik untuk diterima oleh pembaca. 
Ini disebabkan oleh perkembangan personaliti manusia secara lahiriahnya yang berinteraksi.? Perkembangan personaliti ini membantu perkembangan konsep pembentukan perwatakan yang seterusnya mengandungi ciri-ciri persepsi diri dalam pengawalan emosi.

Kajian ini menunjukkan bahawa emosi, personaliti dalam pembinaan watak dan perwatakan merupakan ciri penting dalam plot penceritaan. Kajian ini penting kerana dapat memberikan panduan kepada pengarang dalam membangunkan watak bersama-sama dengan perwatakan seiring dengan personaliti bagi menghasilkan sebuah karya bernilai dan bermutu kualitinya.

\section{RUJUKAN}

Ali Ahmad. (1978). Asas menganalisis cereka. Kuala Lumpur. Dewan Bahasa dan Pustaka.

Allport, G. W. (1960). The open system in personality theory. The Journal of Abnormal and Social Psychology, 61(3), 301-310.

Alfano, M. (2013). Character as moral fiction. Diakses daripada https://www. cambridge.org/core/books/character-as-morafiction/2E8973A58F54F63D84 1875F9E036C54E

Amichai-Hamburger, Y., \& Vinitzky, G. (2010). Social network use and personality. Computers in Human Behavior, 26(6), 1289-1295.

Ando, R. \& Sakamoto, R. (2004). Effect of internet use on depression, loneliness, aggression and preference for internet communication: A panel study with 10- to 12-year-old children in Japan. International Journal of Web Based Communities 4(3), 302-318

Banicki. K. (2017). The character-personality distinction: An historical, conceptual, and functional investigation. Diakses https://journals.sagepub. com/doi/10.1177/0959354316684689

Brinkmann, S. (2010). Character, personality, and identity: Onhistorical aspects of human subjectivity. Nordic Psychology, 62(1), 65-85.

Ekman, P. \& Cordaro, D. T. (2011). "What is meant by calling emotions basic. Emotion Review, 3(4), 364-370.

Feldman Barrett, L. (2001). Idiographic variation in circumplex structure: Affective versus semantic focus (Unpublished manuscript). Boston College.

Fitri Palupi Kusumawati (2013). The personality of the main charactersas? reflected in Paulo Coelho's the devil and miss prym: A psychological studies. Diakses daripada https://www.researchgate.net/publication/319936685.

Gadbois, E. A., \& Dugan, E. (2014). The Big Five Personality factors as predictors of driving status in older adults. Journal of Aging and Health, 1-21.

Gendron, M., Roberson, D., van der Vyver, J. M., \& Barrett, L. F. (2014). Perceptions of emotion from facial expressions are not culturally universal: Evidence from a remote culture. Emotion, 14, 251-262. 
Goldie, P. (2004). On personality. London, UK: Routledge.

Hamza Alshenqeeti. (2016). Are emoji creating a new or old visual language for new generations?: A sociosemiotic study. Advances in Language and Literary Studies, 7(6), 56-9.

Homiak, M. (2015). 'Moral Character', in Edward N. Zalta (Ed.), The Stanford Encyclopedia of Philosophy. Fall 2016 edition.http://plato.stanford.edu/archives/ fall2016/entries/moral-character/

Ismail Ahmad. (1988). Memahami novel dan cerpen. IBS Buku Sdn Bhd.

Izard, C. E. (2009). Emotion theory and research: Highlights, unanswered questions, and emerging issues. Annual Review of Psychology, 60, 1- 25.

Kamariah Kamarudin. (2014). Novel Melayu dalam pelbagai perspektif. Penerbit UPM.

Kristjannsson (2012), Positive psychology and positive education: Old wine in new bottles? April 2012 Educational Psychologist, 47(2), 86-105

Lam Kai Chee \& Kamila Ghazali. (2014). Teknik matched-guised: Mendalami sikap penutur bahasa di Kuching, Sarawak. Jurnal linguistik, 1(18). 48-61

Lavoie, J. A. \& Pychyl, T. A. (2001). Cyberslacking and the procrastination superhighway: A web based survey of online procrastination, attitudes and emotion. Social Sciences Computer Review, 19, 431-444.

Maclyntyre, P. (2013). Personality, attitudes, and affect as predictors of second language communication. Journal of Language an Social Psychology, 15(1), 3-26.

McCrae, R. R., \& Costa, P. T., Jr. (1997). Personality trait structure as a human universal. American Psychologist, 52509-516.

McCrae \& Costa, (1999). A five factor theory of personality. Handbook theory and research. New York: USA

Melanie, J. \& Modecki, L. Kathyrn. (2020) A longitudinal model of rejection sensitivity and internalizing symptom testing emotion regulation deficits as a mechanism and outcome of symptoms. Journal of Personality, https://doi. org/10.1111/jopy.12549

Miller, W. R., \& Rollnick, S. (2013). Applications of motivational interviewing. Motivational interviewing: Helping people change. (3rd edition). Guilford Press.

Mohd Affandi Hassan. (2005). Pendidikan estetika daripada pendekatan tauhid. Dewan Bahasa dan Pustaka.

Mohd Helmi Yusof \& Jamaluddin Aziz. (2018). Pemerkasaan watak wanita dalam filem berunsurkan Islam: Kajian kes “Ketika Cinta bertasbih”. GEMA Online Journal of Language Studies, 18(1), DOI: http://doi.org/10.17576/gema-2018-1801-09

Mompean, Jose. (2010). A corpus-based study of phonological free variation in English. Research in Language, 8, 99-113.

Nor Raudah Hj Siren (2006). E-Dakwah: Kepentingan dan pelaksanaannya di Malaysia” dalam Dakwah Islam Semasa: Konsep dan Pelaksanaan. Penerbit Universiti Malaya, 107-119. 
Nurhamizah Hashim. (2015). Psikologi keperluan remaja dalam novel-novel remaja hadiah sastera kumpulan Utusan. Tesis PhD. Universiti Malaya.

Oatley, K. (1999). Why fiction may be twice as true as fact: Fiction as cognitive and emotional simulation. Review of General Psychology, 3, 101-117.

Padesky, C.A. \& Mooney, K.A. (1986). Presenting the cognitive model to clients. International Cognitive Therapy Newsletter, 6, 13-14.

Padesky, C.A. \& Mooney, K.A. (1990). Presenting the cognitive model to clients. International Cognitive Therapy Newsletter, 6, 13-14.

Palmer, A. (1991). Origin and morphology of limestone caves. Geological Society of American Bulletin. 103.

Rohayati Junaidi, Tengku Intan Marlina Tengku Mohd Ali dan Madiawati Mamat. (2018). Persekitaran kanak-kanak dalam novel beruk format? GEMA Online ${ }^{\circledR}$ Journal of Language Studies, 18(1), http://doi.org/10.17576/gema-2018-1801-07

Saddock \& Ruiz, P. (2015). synopsis of psychiatry: Behavioral sciences clinical psychiatry (11th ed.). Wolters Kluwer.

Samsiah Mohd. Nor. (2012). Ekspresi bahasa wanita dalam novel-novel popular, Tesis kedoktoran, Universiti Kebangsaan Malaysia.

Sailing, L. L., \& Phillips, G. J. (2010). The manifestations of neuroticism in the use of information and communication technology. Journal Psychology of Neuroticism and Shame, 3, 59-83.

Shahnon Ahmad. (1979). Gubahan Novel. Dewan Bahasa dan Pustaka \& Kementerian Pelajaran Malaysia.

Siti Hamim Stapa, \& Azianura Hani Shaari. (2012). Understanding online communicative language features in social networking environment. GEMA Online Journal of Language Studies, 12(3), 817-830. http://ejournal.ukm.my/ gema/article/view/1057/957

Subhan Adrin Sudirman, (2015). Self regulated learning dan persepsi dukungan sosial dengan prestasi akademik mahasiswa fakultas ushuluddin iain imam Bonjol Padang. Studia Insania, 3(1), 19-34.

Woolfolk, R. L. (2002). The power of negative thinking: Truth, melancholia, and the tragic sense of life. Journal of Theoretical and Philosophical Psychology, 22(1), 19-27. https://doi.org/10.1037/h0091192

Zimmer-Gembeck, MJ (2018). Rejection sensitivity and responses to young adults' depression and trait-anxiety. Journal of Relationship-Research, 9, https://doi. org/ 10.1017/jrr.2018.8 